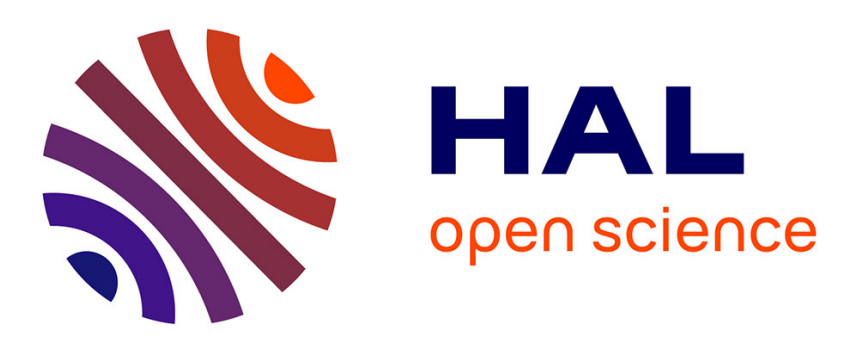

\title{
Synthesis and general properties of silated-hydroxypropyl methylcellulose in prospect of biomedical use.
}

\author{
Xavier Bourges, Pierre Weiss, Guy Daculsi, Gilbert Legeay
}

\section{To cite this version:}

Xavier Bourges, Pierre Weiss, Guy Daculsi, Gilbert Legeay. Synthesis and general properties of silatedhydroxypropyl methylcellulose in prospect of biomedical use.. Advances in Colloid and Interface Science, 2002, 99 (3), pp.215-28. inserm-00198799

\section{HAL Id: inserm-00198799 https://www.hal.inserm.fr/inserm-00198799}

Submitted on 18 Dec 2007

HAL is a multi-disciplinary open access archive for the deposit and dissemination of scientific research documents, whether they are published or not. The documents may come from teaching and research institutions in France or abroad, or from public or private research centers.
L'archive ouverte pluridisciplinaire HAL, est destinée au dépôt et à la diffusion de documents scientifiques de niveau recherche, publiés ou non, émanant des établissements d'enseignement et de recherche français ou étrangers, des laboratoires publics ou privés. 


\section{Synthesis And General Properties Of Silated Hydroxypropyl Methylcellulose In Prospect Of Biomedical Use}

Xavier BOURGES ${ }^{2 *}$, Pierre WEISS ${ }^{2}$, Guy DACULSI $^{2}$ and Gilbert LEGEAY ${ }^{1}$.

1 : Centre de Transfert de Technologie du Mans, 20 rue Thalès de Milet, 72000 Le Mans France: glegeay@cttm-lemans.com

2 : INSERM E 99-03, Laboratoire des Tissus Calcifiés, Faculté de Chirurgie Dentaire, 1 place Alexis Ricordeau, 44042 Nantes France: xavier.bourges@sante.univ-nantes.fr * corresponding author 


\begin{abstract}
Synthesis of grafting silane on a hydro soluble cellulose ether (HPMC) was described. In alkaline medium, this derivate is under gel form. With a decrease of the $\mathrm{pH}$, a self-hardening occurs due to the silanol condensation. For potential biomedical use, we described the silated HPMC synthesis, the gel behavior after steam sterilization and the parameters of the silanol condensation i.e. $\mathrm{pH}$, silane percentage ant temperature. Minimum kinetic of the condensation was observed for $\mathrm{pH}$ between 5.5 and 6.5 . So temperature catalyzed the reaction and the selfhardening speed was increased by silane percentage.
\end{abstract}

Keywords: silane, silanol, synthesis, HPMC, condensation 


\section{Introduction}

The development of bone substitutes opens new ways, in particular endoscopics methods and materials allow creating injectable forms generating operations less important by its surgical acts, easiness for the patricians and comfort for the patients. Calcium phosphate cements and PMMA were the first products used as bone substitutes in orthopaedic surgery, stomatology and dental applications. The first injectable form developed to the laboratory is composed of a hydro soluble cellulose ether added to phosphate calcium ceramic granules $(1,2)$. Ceramic used is a mixture of hydroxyapatite (HA) and $\beta$-tricalcium phosphate $(\beta$-TCP) called biphasic calcium phosphate (BCP). This ceramic is obtained after sintering of a calcium deficient apatite. $\mathrm{BCP}$ is biodegradable after implantation along the time with good healing properties and its uses are essentially for orthopaedic surgery and stomatology under blocs, cylinders, coins or granules forms $(3,4,5,6,7)$. The hydro soluble cellulose ether is hydroxypropyl methylcellulose (HPMC), the polymer is prepared at $3 \%$ in water $(\mathrm{w} / \mathrm{w})$ and mixed to the BCP granules with a ratio $50: 50(\mathrm{w} / \mathrm{w})$ and sterilised to the autoclave $\left(121^{\circ} \mathrm{C}\right.$ for 20 minutes). The injectable bone substitute (IBS) is ready to use, and first experiments on animals showed that IBS generated some good healings of bone defects $(8,9,10)$. Choice of HPMC as the vector phase of BCP granules were realised on its properties and uses in biomedical application. This polymer in solution is used in ophthalmologic surgery for setting intra-ocular lenses $(11,12)$, it can be add to the phosphate calcium cement as to control the rheology (13). But its principal applications are for tablet sealing and binder. Methylcellulose (MC), which is the origin of HPMC, is used like medium for cell culture (14). With these various uses, MC and HPMC show that they are really non-toxic. They are stable over a wide range of temperatures (can be autoclaved without great loss of viscosity (15)) and $\mathrm{pH}$ between 3 and 11. Nevertheless, increasing temperature of HPMC and MC gels generates a cloud point 
defined between $50^{\circ} \mathrm{C}$ and $80^{\circ} \mathrm{C}$ according to the percentages of methyl and hydroxypropyl on the cellulose $(16,17)$. This phenomenon is reversible with the decreasing temperature.

In this article, we present the synthesis and properties of a new gel based on a derivate from HPMC, this form self-hardens without toxic catalyst, generating a gelatine like structure. The development of this gel must decrease the flow tendency and increase mechanical properties of the IBS after implantation.

The self-hardening principle of the gel is based on the silanes grafted by different functions (glycidoxy, vinyl or halogen acyls) along the HPMC chains (silated HPMC), dissolution of this product takes place in strong basic middle $(\mathrm{pH}=13.2)$ which corresponds to the silane ionisation into sodium silanolate. This silicon ionisation is described essentially for the silica gel with various bases in aqueous solution (18).

The limit $\mathrm{pH}$ of sodium silanolate stabilisation is about 12.1-12.2. After sodium silanolates transform into silanols. These lasts react each others by condensation, forming a three-dimensional network of the HPMC chains (fig. 1.). Silanol is widely used as intermediate in the silicone synthesis (19); the other industrial application is in the HPLC columns, silanol functions were generated at the silica surface, after they can be modified by grafting of various alkyl chains (20).

(1)
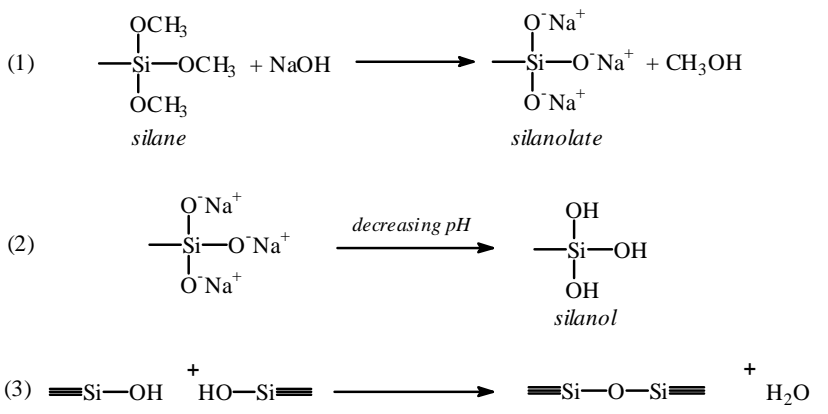

Figure 1. Silane behaviors grafted on the HPMC: (1) dissolution in basic middle with silanolate function formation, (2) decrease $\mathrm{pH}$ generates silanolate transformation into silanol, (3) silanol condensation. 
So it was studied the silated HPMC synthesis with some different silane volume, which modify only the grafted silane percentages on HPMC, these last were determined by calculation from the silicon percentage, already works were performed with silated hydroxyethylcellulose (21), but this polymer is very sensitive to the alkaline solution: it was observed a high decrease viscosity. Then the idea was to develop the silated HPMC.

Steam sterilisation effect was studied on HPMC solution, in different concentrations of hydroxide sodium and polymer, in order that the HPMC stability can be determine in alkaline conditions, for the following steps with silated HPMC. Literature describes loss of viscosity with the $\mathrm{pH}$ increase. This loss is due to the modification of the macromolecular conformation (16) and a light degradation of the glycosidic linkage.

Complete dissolution of silated HPMC takes place in a strong basic middle $\left(2.10^{-1} \mathrm{M}\right.$ $\mathrm{NaOH}$ ) with a duration between 2 and 5 hours. This concentration stays important, and as it was seen previously, silated HPMC react for $\mathrm{pH}$ between 12.2-12.4, so it is possible to decrease $\mathrm{NaOH}$ concentration until these values limit. To decrease $\mathrm{pH}$, the addition of strong or low acid had been excluded because of the silanolate sensibility to react. The chosen method was the dialysis in different $\mathrm{NaOH}$ solutions (lowest $2.10^{-1} \mathrm{M}$ ). So, all silated HPMC were used 10 days after sterilisation and stored at $40^{\circ} \mathrm{C}$. After this period, silated gels are ready to use. We measured the apparent viscosity of the HPMC in alkaline conditions and the silated HPMC as to compare them.

In the last step, it was studied the self-hardening of the silated HPMC gel in function of the neutralisation $\mathrm{pH}$, obtained after mixing with different low acids. Next, the studies were restricted with $\mathrm{pH}$ equal to 7.0 and 7.3 , because these $\mathrm{pH}$ near neutrality are acceptable for first simulation of body implantation. And self-hardening kinetics were followed in function of the grafted silane percentage and the temperature. 


\section{Materials and methods}

Synthesis of HPMC-silated

Four syntheses were realised with different volumes of 3glycidoxypropyltrimethoxysilane (GPTMS) which is the group to graft and a product designation were affected for each synthesis with different GPTMS volume: $4 \mathrm{ml}$ - P(4); $5 \mathrm{ml}$ - $\mathrm{P}(5) ; 6 \mathrm{ml}-\mathrm{P}(6)$ and $7 \mathrm{ml}-\mathrm{P}(7)$. In a ball glass (tricol: 1 litre), $316 \mathrm{ml}$ of n-Heptane (Acros) were stirred with $70 \mathrm{ml}$ of 1-Propanol (Acros). $2 \mathrm{~g}$ of hydroxide sodium and 38,6 $\mathrm{g}$ of dry HPMC $\left(\mathrm{E} 4 \mathrm{M}{ }^{\circledR}\right.$ Colorcon-Kent-England, $\mathrm{Mw}=290000 \mathrm{~g} / \mathrm{mol}$ as determined by light scattering) were added to the mixture under stirring. The mixture was kept at room temperature for 45 minutes under a nitrogen bubbling. In function of the synthesis, GPTMS was added drop wise and temperature was increased until $100^{\circ} \mathrm{C}$ in 35 minutes. The boiling was maintained for 3 hours. Heating was closed and at $40^{\circ} \mathrm{C}, 5 \mathrm{ml}$ of acetic acid glacial was poured for the reaction neutralisation, after 30 minutes, the mixture was filtered on a buschner and rinsed 2 times with $50 \mathrm{ml}$ of acetone. The white powder was dried at $50^{\circ} \mathrm{C}$ under vacuum for 1 hour. The dried powder was washed successively three times with $500 \mathrm{ml}$ of a mixture acetone/water $(85: 15(\mathrm{v} / \mathrm{v}))$ and silated HPMC powders were dried at $50^{\circ} \mathrm{C}$ overnight.

The washes with the mixture acetone/water allow the elimination of the by-products created during the reaction (sodium acetate) and products (NaOH and GPTMS). FTIR studies were realised with a Magna 550-Nicolet, HPMC and silated HPMC samples were at $1 \%$ in $\mathrm{KBr}$, and 3-glycidoxypropyltrimethoxysilane spectrum was made with a $\mathrm{CaF}_{2}$ cell $(5 \mu \mathrm{m})$.

The silicon percentages grafted on HPMC for the different synthesis were determined by Inductively Coupled Plasma Atomic Emission Spectroscopy (ICP-AES). This result allows to calculate the silane percentage and the reaction yield.

Preparation of silated HPMC solution 
Silated HPMC powders are only soluble at basic $\mathrm{pH}$ (minimum $[\mathrm{NaOH}]=1.10^{-1} \mathrm{M}$ ), more the $\mathrm{NaOH}$ concentration is important more the dissolution is quick. Preliminaries studies allowed select an $\mathrm{NaOH}$ concentration equal to $2.10^{-1} \mathrm{M}$ generating a quick dissolution whatever the silated HPMC concentration in solution and the grafting silane percentage on HPMC, dissolution varies between 2 and 5 hours. Nevertheless, when the dissolution is total, it is possible to decrease $\mathrm{NaOH}$ concentration by dialysis without gel crosslinking but with a limit concentration in $\mathrm{NaOH}$ about $2.10^{-2} \mathrm{M}$ and $3.10^{-2} \mathrm{M}$ (pH between 12.2 and 12.4). Because under this limit, sodium silanolates transform into silanol and the crosslinking gel begins. From silated HPMC gels at $2.10^{-1} \mathrm{M} \mathrm{NaOH}$, it was decreased $\mathrm{NaOH}$ concentration at the value desired $\left(9.10^{-2} \mathrm{M}, 7.10^{-2} \mathrm{M}\right.$ and $\left.5.10^{-2} \mathrm{M}\right)$. Dialysis protocol is the following, silated-HPMC gels at $2.10^{-1} \mathrm{M} \mathrm{NaOH}(300 \mathrm{~g}-400 \mathrm{~g})$ were disposed in dialysis bag (Spectra-por 6-8000) and four baths (4 litres each one) of the different $\mathrm{NaOH}$ concentration to study were changed successively. Durations were respectively 1, 1, 1 and 15 hours.

\section{$\underline{\text { Steam sterilization effect }}$}

For non grafted HPMC, two concentrations were retained for this study which were respectively at 3 and 3,5\% in solution. The $\mathrm{NaOH}$ concentrations for the solutions were $1.10^{-}$ ${ }^{2} \mathrm{M}, 5.10^{-2} \mathrm{M}, 1.10^{-1} \mathrm{M}, 2.10^{-1} \mathrm{M}$ and $4.10^{-1} \mathrm{M}$. Blanks were realized with deionised water and $\mathrm{pH}$ of the gels were measured with a titrator Mettler Toledo DL 53. 2 days after their preparation, gels were sterilised at the autoclave (Matachana $21 \mathrm{Le}$ ): $121^{\circ} \mathrm{C}$ for 20 minutes. 3 days after the sterilisation (time necessary for the recovery of the gel structure), viscosities of the gel were measured with a viscometer Rheovisco (type 2) equipped with spindles DIN (1 $\mathrm{rpm} / \mathrm{min}$ at $\left.25^{\circ} \mathrm{C}\right)$.

For silated HPMC gels, also two concentrations were studied, one at 3\%(w/w) and the other at $3.5 \%(\mathrm{w} / \mathrm{w})$ with product $\mathrm{P}(6)$. $\mathrm{NaOH}$ concentrations was $2.10^{-1} \mathrm{M}$. Before sterilisation, viscosities of silated HPMC were noticed. For sterilised products, measures were 
realised 10 days after sterilisation with a viscometer Rheovisco type 2 at $25^{\circ} \mathrm{C}$ equipped of spindles DIN.

\section{Self-hardening property of HPMC-silated in function of the $\mathrm{pH}$}

For this study, increasing viscosity is the analysis method. Chosen product was $\mathrm{P}(6)$. Dissolution at $3 \%(\mathrm{w} / \mathrm{w})$ took place in $2.10^{-1} \mathrm{M} \mathrm{NaOH}$ solution. The gel was dialysed at $5.10^{-2}$ $\mathrm{M} \mathrm{NaOH}$ as described previously and sterilised at autoclave in closed vials $\left(121^{\circ} \mathrm{C}\right.$ for 20 minutes). Measures were realised 10 days after sterilisation. To obtain various buffered gels from $\mathrm{NaOH}$ solutions, two acid salts were chosen for their properties of final $\mathrm{pH}$ : citric acid (Fisher) and sodium dihydrogenphosphate (Riedel-de Haën). 2,3 $\mathrm{ml}$ acid solution at various concentrations was stirred carefully with $10 \mathrm{~g}$ of silated HPMC gel. Citric acid allows to obtain gel $\mathrm{pH}$ between 3 and 6 whereas with sodium dihydrogenphosphate, $\mathrm{pH}$ is between 6.5 and 8. As soon as the mixtures were homogeneous, they were disposed with a syringe in the cylinder of measure conditioned at $25^{\circ} \mathrm{C}$. The crosslinking kinetics were realized with a viscometer Rheovisco type 2 equipped of spindles for high viscosity (S-28). Times were noticed for viscosity equal to $1,5.10^{5} \mathrm{mPa}$.s. Then experiments were restricted to $\mathrm{pH} 7$ and 7.3, product was $\mathrm{P}(6)$ at $3 \%$ in $9.10^{-2} \mathrm{M} \mathrm{NaOH}$ concentration. In accordance to the $\mathrm{pH}$ desired, two concentrations of $\mathrm{NaH}_{2} \mathrm{PO}_{4}$ were prepared: for $\mathrm{pH}$ equal to $7 \mathrm{a} \mathrm{NaH}_{2} \mathrm{PO}_{4}$ solution at $6.10^{-1} \mathrm{M}$ and for $\mathrm{pH}$ equal to $7.3 \mathrm{a} \mathrm{NaH}_{2} \mathrm{PO}_{4}$ solution at $5.10^{-1} \mathrm{M}$. In each case $2.3 \mathrm{ml}$ of the two solutions are mixed at $10 \mathrm{~g}$ of silated HPMC gel, viscosities were noticed each minute until to have values about $1,5 \cdot 10^{5} \mathrm{mPa}$.s.

\section{Others parameters of kinetic crosslinking silated HPMC}

a- In function of grafted silane percentage.

First works were realized with a first series of HPMC-silated with $\mathrm{P}(5)$ and $\mathrm{P}(6)$ prepared at $3 \%$ and a second series with $\mathrm{P}(4), \mathrm{P}(5)$ and $\mathrm{P}(6)$ prepared at 3.5\%. All gels were prepared in $9.10^{-2} \mathrm{M} \mathrm{NaOH}$ concentration; then they were sterilised at autoclave. After 10 
days, they were analysed. For the two series, $10 \mathrm{~g}$ of gel were neutralised by $2.3 \mathrm{ml}$ of a $\mathrm{NaH}_{2} \mathrm{PO}_{4}$ solution at $5.10^{-1} \mathrm{M}$, these mixtures allowed to obtain a $\mathrm{pH}$ value about 7.3 at $25^{\circ} \mathrm{C}$. Analyses were performed with the viscometer, and viscosities were noticed each minute until to have values about $1,5 \cdot 10^{5} \mathrm{mPa} . \mathrm{s}$.

b- In function of the temperature $\left(25\right.$ and $\left.37^{\circ} \mathrm{C}\right)$

Experiments were realised with $\mathrm{P}(7)$, gel was at $3 \%(\mathrm{w} / \mathrm{w})$ in a $\mathrm{NaOH}$ solution at $9.10^{-}$ ${ }^{2} \mathrm{M}$. $10 \mathrm{~g}$ of gel were neutralised by $2.3 \mathrm{ml} \mathrm{NaH} \mathrm{PO}_{4}$ solution at $6.10^{-1} \mathrm{M}(\mathrm{pH}=7)$. Viscosity measures were realised at 25 and $37^{\circ} \mathrm{C}$. Before mixes, gels and neutralisation solution were conditioned to the measure temperature.

\section{Results}

$\underline{\text { Studies on the silated HPMC powders: yield reaction and FTIR }}$

FTIR analyses did not shown any difference between silated HPMC and non-grafted HPMC (fig. 2.). GPTMS spectrum presents one part of bands similar to the HPMC spectrum.

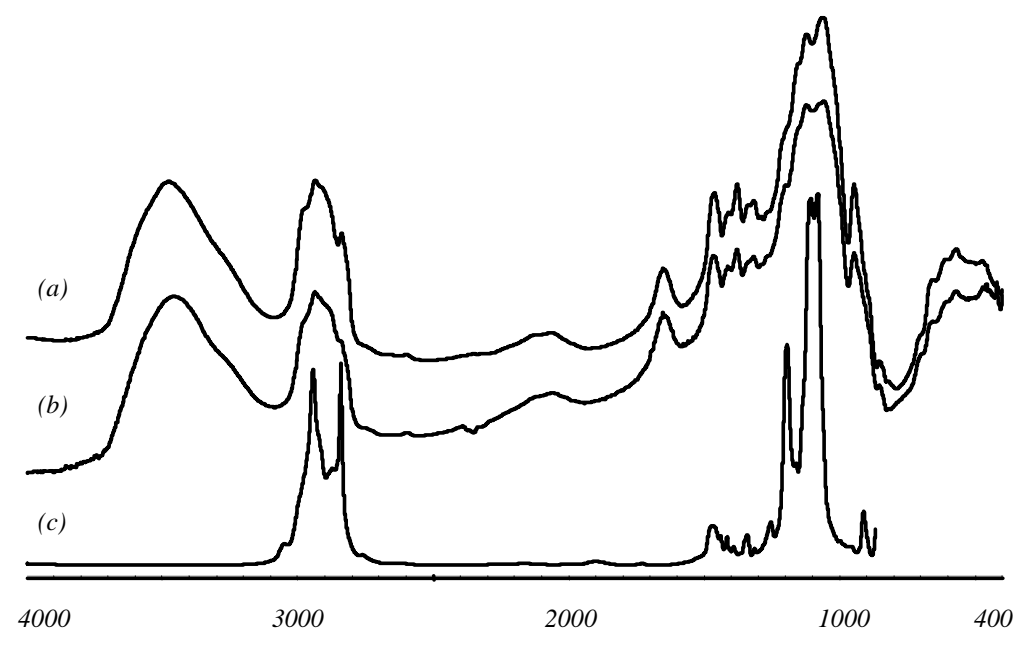

Figure 2. FTIR spectra: (a) HPMC, (b) silated-HPMC and (c) 3glycidoxipropyltrimethoxysilane.

The others bands are not detectable, because they are not enough strong to be detecting by FTIR. Nevertheless FTIR indicated that HPMC was not chemically modified by synthesis. So 
as to determine the grafted silane, ICP-AES was used. This analysis method allowed to obtain the silicon percentage and to deduct the silane percentage on HPMC, this last value was generated the reaction yield. Formulas were the followings (with $M_{\text {gptms }}=236.34 \mathrm{~g} / \mathrm{mol}$, $d_{\text {gptms }}=1.070$, silane volume in $\mathrm{ml}(\mathrm{vol})$ and HPMC weight in $\mathrm{g}(\mathrm{m}), \%$ silane $(100)$ represents the maximum grafted percentage possible on HPMC in accordance with the silane volume added to the synthesis).

$$
\begin{aligned}
& \% \text { silane grafted }=\frac{(\% \text { Si-\% Si }(E 4 M)) \times M_{\text {gptms }}}{M_{S i}} \times 100 \\
& \% \text { silane }(100)=\frac{\text { vol } \times d}{m+(\text { vol } \times d)} \times 100 \\
& \text { Yield }(\%)=\frac{\% \text { grafted silane }}{\% \text { silane }(100)} \times 100
\end{aligned}
$$

\begin{tabular}{|c|c|c|c|c|c|c|}
\hline $\begin{array}{c}\text { Product } \\
\text { designation }\end{array}$ & $\begin{array}{c}\text { Silane } \\
\text { volume } \\
(\mathrm{ml})\end{array}$ & $\begin{array}{l}\% \mathrm{Si} \\
(\mathrm{w} / \mathrm{w})\end{array}$ & $\begin{array}{c}\% \text { silane } \\
\text { grafted }(w / w)\end{array}$ & $\begin{array}{c}\% \text { silane (100) } \\
(\mathrm{w} / \mathrm{w})\end{array}$ & Yield & \\
\hline E4M & - & 0.064 & - & - & - & \\
\hline $\mathrm{P}(4)$ & 4 & 1.06 & 8.41 & 9.97 & 84.35 & \\
\hline $\mathrm{P}(5)$ & 5 & 1.25 & 10.01 & 12.16 & 82.33 & \\
\hline $\mathrm{P}(6)$ & 6 & 1.53 & 12.37 & 14.24 & 86.86 & \\
\hline $\mathrm{P}(7)$ & 7 & 1.72 & 13.96 & 16.23 & 86.01 & 1. Results of the \\
\hline
\end{tabular}

Results were represented in table 1.

different silated HPMC syntheses, silicon percentages (\% Si) were obtained by ICP-AES, silane grafted percentages, silane (100) percentage and yield were calculated.

Whatever the GPTMS volume added to the synthesis, the yields were reproducible and important (82.3-86.0\%). So grafted silane percentage $(\mathrm{w} / \mathrm{w})$ could varied between 8.9 and $14.0 \%$. These values were of primary importance for the explanations of the result 
experiments to come, because in according to the silated HPMC, self-hardening speed properties will be modified.

\section{$\underline{\text { Viscosities of non and silated HPMC }}$}

Viscosity results of the non grafted HPMC were represented in figure 3. Without sterilization and for the two concentrations, gel viscosity was decreased slightly with the increase $\mathrm{pH}$. Sterilized products showed a viscosity decrease all the more because $\mathrm{pH}$ increases. The gels were stables in deionised water $(\mathrm{pH}=7)$ after sterilization. At $\mathrm{pH}$ equal to 12.8, i.e. $\mathrm{NaOH}$ concentration equal to $2.10^{-1} \mathrm{M}$, viscosity loss for the two concentrations are respectively 33 and $36 \%$ in comparison with products in deionised water. This $\mathrm{NaOH}$ concentration served of reference for the silated HPMC because they were dissolved in this medium. Nevertheless it was preserved sufficient viscosity for the IBS application.

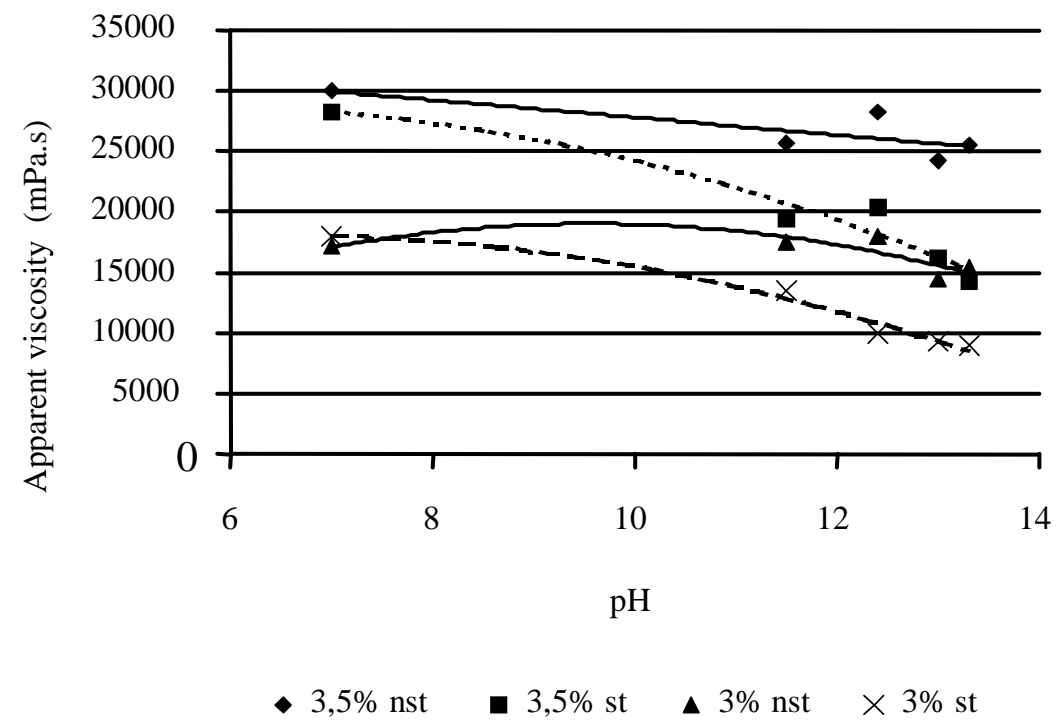

Figure 3. Apparent viscosity's of HPMC at 3 and $3.5 \%(\mathrm{w} / \mathrm{w})$ in $\mathrm{NaOH}$ solution at $0.2 \mathrm{M}$, with and without sterilization.

To verify the silated HPMC stability with and without sterilization, it was studied the viscosity in function of the concentration ( 3 and $3.5 \%$ ) at a $\mathrm{NaOH}$ concentration equal to $2.10^{-}$

${ }^{1} \mathrm{M}$. The results whole was represented in figure 4. 


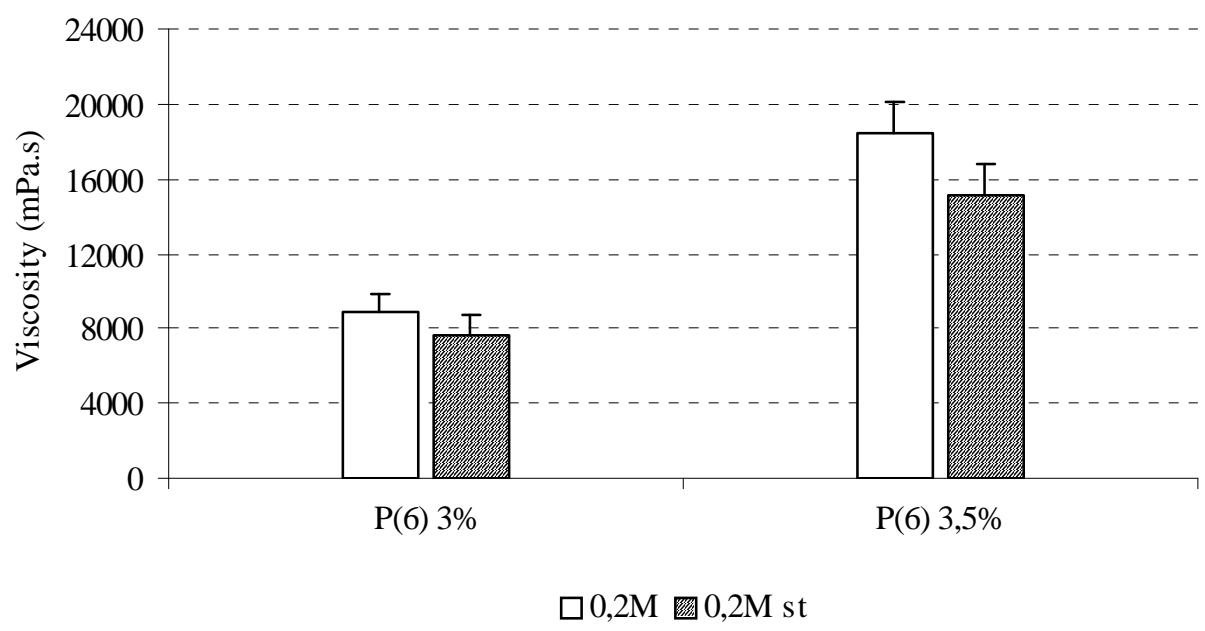

Figure 4. Apparent viscosity's of silated HPMC P(6) at different concentration (3 and 3.5\% $(\mathrm{w} / \mathrm{w}))$ and in different $\mathrm{NaOH}$ solution, before and without sterilization.

At $2.10^{-1} \mathrm{M} \mathrm{NaOH}$, without sterilization, viscosity results were not in accordance with the previous HPMC study in same conditions, there is a viscosity loss. After steam sterilization and a 10 days period, there is a viscosity decrease. So in comparison with HPMC non-grafted, sterilized silated HPMC $\left(2.10^{-1} \mathrm{M}\right)$ lost about the same viscosity percentage after sterilization. At $3 \%$ in concentration after steam sterilization, silated-HPMC viscosities were about $7000 \mathrm{mPa} . \mathrm{s}$; and for $3.5 \%$ in concentration, gel viscosities were about $14000 \mathrm{mPa} . \mathrm{s}$.

\section{Self-hardening property in function of the $\mathrm{pH}$}

This study was realized with $\mathrm{P}(6)$ at $3 \%$ in concentration and in a $\mathrm{NaOH}$ solution at $5.10^{-2} \mathrm{M}$. At each $\mathrm{pH}$ obtained $20 \mathrm{~g}$ of the gel were neutralized by $2.3 \mathrm{ml}$ of various low acids at different concentrations. Times ( $\mathrm{t}$ ) to obtain a viscosity of $1.10^{5} \mathrm{mPa}$.s were noticed and calculations of $\log (1 / \mathrm{t})$ were realized. These values were represented in table 2 , figure 5 presents $\log (1 / \mathrm{t})$ in function of the $\mathrm{pH}$. 


\begin{tabular}{|c|c|c|c|}
\hline Neutralisation solution & Final $\mathrm{pH}$ & $\begin{array}{c}\text { Times in minutes } \\
(\mathrm{t})\end{array}$ & $\log (1 / t)$ \\
\hline Citric acid $0.15 \mathrm{M}$ & 4.7 & 54 & -1.73 \\
\hline Citric acid $0.11 \mathrm{M}$ & 5.3 & 174 & -2.24 \\
\hline Citric acid $0.1 \mathrm{M}$ & 5.6 & 278 & -2.44 \\
\hline Citric acid $0.08 \mathrm{M}$ & 6.5 & 84 & -1.92 \\
\hline $\mathrm{NaH}_{2} \mathrm{PO}_{4} \quad 0.4 \mathrm{M}$ & 6.9 & 34 & -1.53 \\
\hline $\mathrm{NaH}_{2} \mathrm{PO}_{4} \quad 0.3 \mathrm{M}$ & 7.2 & 14 & -1.15 \\
\hline $\mathrm{NaH}_{2} \mathrm{PO}_{4} \quad 0.25 \mathrm{M}$ & 7.77 & 4 & -0.6 \\
\hline
\end{tabular}

Table 2. Neutralization solutions

of the gel with the final $\mathrm{pH}$ of the mixes, times necessary for a viscosity equal to $1.10^{5} \mathrm{mPa} . \mathrm{s}$ were noticed and $\log (1 / \mathrm{t})$ were calculated for each value.

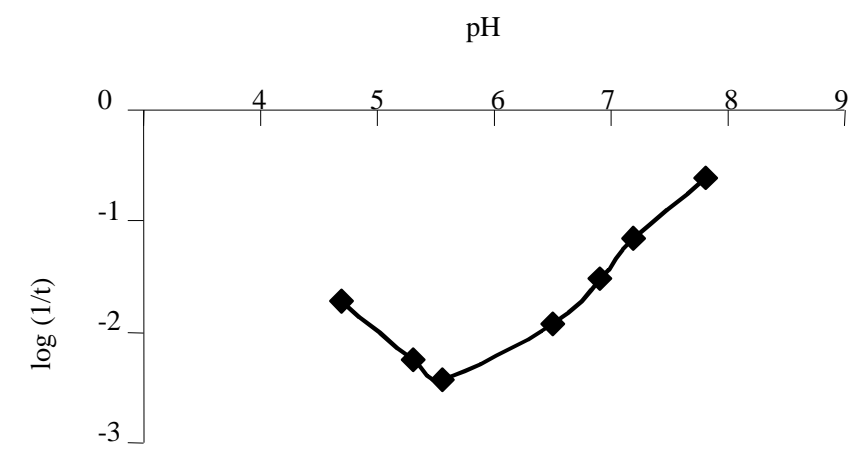

Figure 5. Representation of the self-hardening kinetics of $\mathrm{P}(6) 3 \% 0.05 \mathrm{M}$ in function of the $\mathrm{pH}$.

Results showed that the reaction was catalyzed in acidic or basic middle with a minimum rate between 5.6 and 6.5. Reactivity difference was very marked at $\mathrm{pH}$ equal 7,77, time is 4 minutes and for the slowest, time is 278 minutes. So as to observe the real difference between two near $\mathrm{pH}$, it was studied for a same product $(\mathrm{P}(6) 3 \%)$ the self-hardening evolution by viscosity method at $\mathrm{pH} 7.0$ and 7.3 at $25^{\circ} \mathrm{C}$. Results were represented figure 6 .

Decrease of the $\mathrm{pH}$ generated a lower speed of the silanol condensation. And it was noticed a self-hardening speed exponential. 


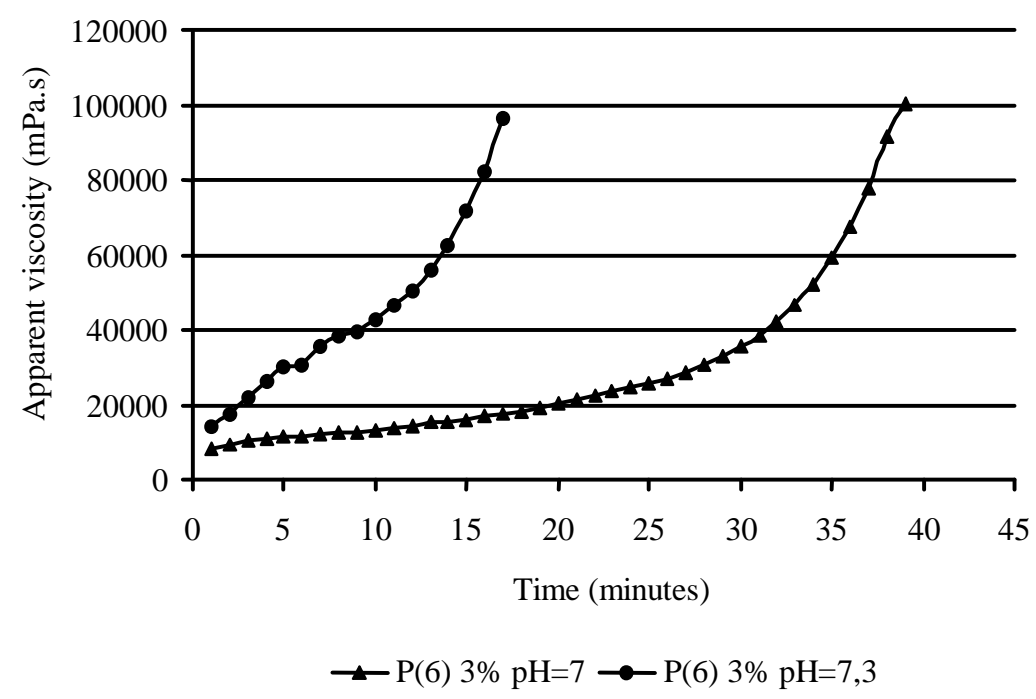

Figure 6. Representation of the self-hardening evolution in function of the time for $\mathrm{P}(6) 3 \%$ at $\mathrm{pH}=7$ and $\mathrm{pH}=7.3$.

\section{Parameters studies influencing the self hardening}

Five products were studied, two with an original concentration at 3\%: $\mathrm{P}(5)$ and $\mathrm{P}(6)$. Three others with an original concentration at 3.5\%: $\mathrm{P}(4), \mathrm{P}(5)$ and $\mathrm{P}(6)$. For a same product, a higher silated HPMC concentration generated the viscosity increase. Also, it was calculated the silane concentration of each gel after $\mathrm{NaH}_{2} \mathrm{PO}_{4}$ neutralization at $\mathrm{pH} 7,3$. For $3 \%$ in polymer concentration, silane concentration for $\mathrm{P}(5)$ and $\mathrm{P}(6)$ were respectively $2,46.10^{-1}$ and $3,04.10^{-1} \%(\mathrm{w} / \mathrm{w})$. For the gels at $3.5 \%$ in polymer concentration: $\mathrm{P}(4), \mathrm{P}(5)$ and $\mathrm{P}(6)$ had respectively $2,41.10^{-1}, 2,8710^{-1}$ and $3,55.10^{-1} \%(\mathrm{w} / \mathrm{w})$ of silane concentration. Self-hardening kinetics were represented in figure 7. 


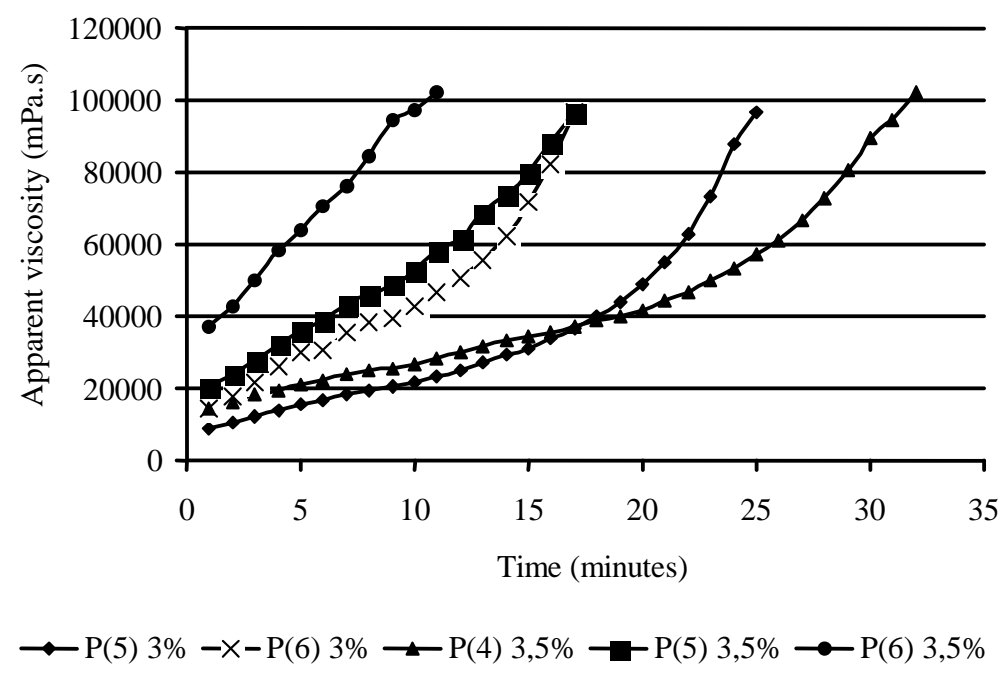

Figure 7. Representation of the self-hardening evolution in function of the time for different silated HPMC.

In resolving on the silane concentrations, it was shown that the self-hardening depended essentially from this parameter. More this value is high, more the self-hardening speeds are important. That is verified with product at $3.5 \%$ in polymer concentration. Study on the gel concentration in function of the silane concentration with the products followings, $\mathrm{P}(5) 3 \%$ and $\mathrm{P}(4) 3.5 \%$ which had both similar silane concentration, showed that $\mathrm{P}(4)\left(2.411^{-1} 1 \%\right)$ had a self-hardening speed much lower $\mathrm{P}(5)\left(2,4610^{-1} \%\right)$, in spite of a greatest viscosity at the origin.

Temperature parameter was studied (fig. 8.); for this experiment the silated HPMC was $\mathrm{P}(7)$ at $3 \%$ in concentration. Chosen $\mathrm{pH}$ was 7 at 25 and $37^{\circ} \mathrm{C}$. It was observed that temperature had an important rule in the self-hardening speed, in fact for $\mathrm{P}(7)$ the speeds were very different: temperature catalyzed the silanol condensation. Also the self-hardening kinetics were exponential. 


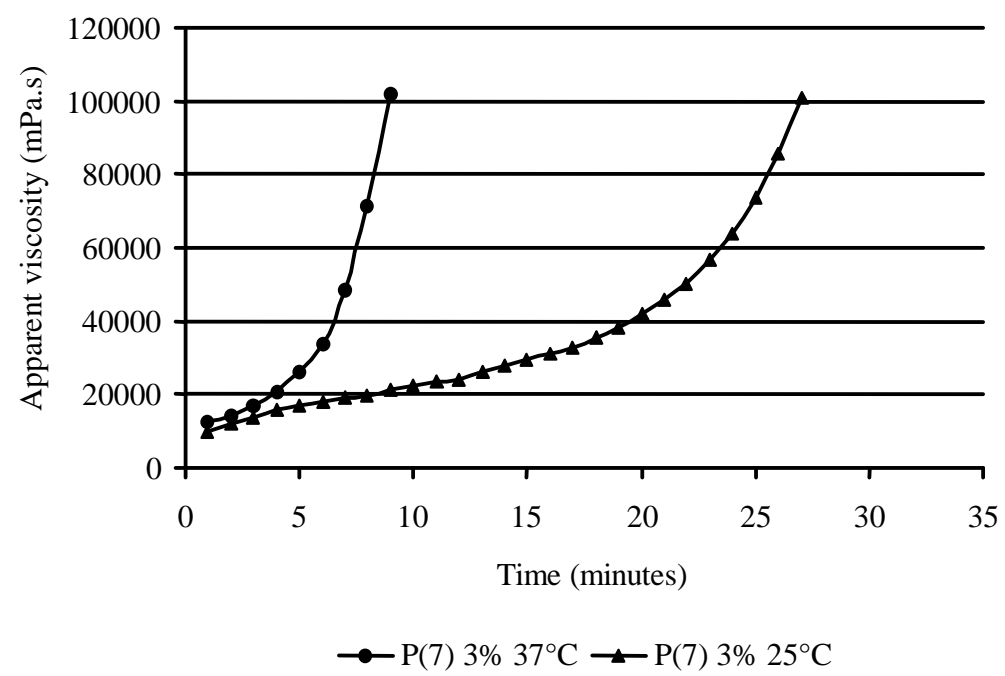

Figure 8. Representation of the self-hardening evolution in function of the time for $\mathrm{P}(7) 3 \%$, $\mathrm{pH}=7$ at 25 and $37^{\circ} \mathrm{C}$.

\section{Discussion}

The viscosity study of HPMC after sterilization showed that the product was stable in deionized water even after sterilization. Nevertheless in basic medium, viscosity HPMC decreased. Sterilization generated a viscosity decrease. Most of the polysaccharides, and in particular cellulose ethers are sensible to the $\mathrm{pH}$, there is not chemical degradation but preferably a salting out phenomenon and some random glycosidic breaking along the cellulosic chain. To degrade cellulose, it is necessary to have some high $\mathrm{NaOH}$ concentration (22). In spite of a loss viscosity, HPMC was adequate for silane grafting. Sau $(23,24)$ was the first to describe silated-polysaccharide synthesis with hydroxyethylcellulose (HEC) and HPMC in the goal to obtain insoluble films of the cellulose ethers. Some preliminaries works were realized on a silated HEC to do a self-hardening gel for potential biomedical use $(25,26)$. In this article, it was described the synthesis of silated HPMC (which differs of the original synthesis described by $\mathrm{Sau}$ ) and the self-hardening properties in function of the $\mathrm{pH}$, silane percentage and temperature. These parameters were not studied until now.

The silated HPMC synthesis was simple by its process, its reactives and solvents used. The yields were excellent and similar between them (82.3-86.0\%). In comparison with 
silated HEC yields which were about 55 and 66\% (26), the results with silated HPMC are largely upper. Yield calculation were realized with the silicon percentage obtained by ICPAES assay. This method allowed having a reliable result. The silane percentage varied from 8.4 to $14 \%$ in accordance to the volume added for the syntheses. Nevertheless, it was not known what is the maximum of silane being able to graft on HPMC. So FTIR spectra from silated-HPMC did not show the silane grafting because most of GPTMS bands were superposable with HPMC bands, but it was not observed oxidation bands.

For the viscosity results on the silated-HPMC non sterilized, there was a decreasing in comparison with HPMC non grafted. That can be explained by the synthesis itself, which was realized at high temperature generating a macromolecular modification. Nevertheless product at $3.5 \%$, after dialysis and sterilization, allowed having sufficient viscosity (14 000mPa.s) for an injectable bone substitute.

The study of the self-hardening properties revealed three parameters. Firstly, the gel $\mathrm{pH}$ after neutralization generated various speeds. Silanol condensation were catalyzed in acid or basic medium with a $\mathrm{pH}$ minimum between 5.5 and 6.5. Original viscosity of the gels after neutralization were between 5000 and $14000 \mathrm{mPa}$.s in accordance to the silated-HPMC concentration; and to obtain a viscosity equal to $1.10^{5} \mathrm{mPa}$.s minimum time required were 5 minutes, for the slowest 278 minutes; this elapsed time is very important. This phenomenon was described in $\mathrm{D}_{2} \mathrm{O}$ medium by Pohl et al. with aminopropyltriethoxysilane (27). Then it was important to restrict the study at $\mathrm{pH}$ near neutrality as to know better its behaviors, because in body implantation, fluids buffered at $\mathrm{pH} 7.4$ can help to the self-hardening if gels had original $\mathrm{pH}$ equal to 7 . The study of this parameter showed that in comparison with $\mathrm{pH}$ 7.0 condensation was twice fast at $\mathrm{pH}$ equal to 7.3. Silated HPMC gels buffered at $\mathrm{pH} 7.0$ self hardened slowly during application, but after implantation $\mathrm{pH}$ of the body can accelerate the silanol condensation. 
The last parameter studied was the used temperature. Like we described previously, product must be used easily at room temperature and self-hardened quickly after implantation. Speed self-hardening comparison between 25 and $37^{\circ} \mathrm{C}$ was underlined than temperature catalyzed favorably the silanol condensation.

\section{Conclusion}

The whole results showed that the product must be neutralized at $\mathrm{pH} 7$ as to allow an easy use without untimely condensation at room temperature. This $\mathrm{pH}$ generated some good conditions for the cellular environment of the bone defect. In this article we did not study the final hardness of the cross-linking gel, we will study in the future. And it could be study in details the silanol condensation by FT-Raman spectroscopy (28) or ${ }^{29} \mathrm{Si}$ NMR (29). Essentially, we will look biocompatibility in vitro of the silated HPMC, some works were already realized with osteoblast cells in HPMC solution, and they did not show toxic effect (30). This original product could be used like a scaffold for cell culture (31) and implanted in bone defect and use for cartilage model. Also we can substitute gelatin applications by this new product, because it's a molding material at ambient temperature and it is from cellulosic origin without pathogen agent.

\section{Bibliography}

(1) G. Daculsi, P. Weiss, J. Delecrin, G. Grimandi, N. Passuti and F.Guerin, Int. Pat. WO $95 / 21634$ 
(2) G.Daculsi, P. Weiss, J.M. Bouler, O. Gauthier, F. Millot and E. Aguado, Bone, 25(2) (1999) 59S.

(3) M. Jarcho, Clin. Orthop., 157 (1981), 259.

(4) R.Z. Legeros, Calcium phosphate materials in restorative dentistery: A review. Adv. Dent. Res., 2 (1988) 164.

(5) G. Daculsi and N. Passuti, Clin. Orthop., 248 (1989) 169.

(6) G. Daculsi, N. Passuti, S. Martin, C. Deudon, R.Z. Legeros and S. Raher, J. Biomed. Mater. Res., 24 (1990) 379.

(7) G. Daculsi, R.Z. Legeros, E. Nery, K. Lynch and B. Kerebel, J. Biomed. Mater. Res., 23 (1989) 883.

(8) G. Grimandi, P. Weiss, F. Millot and G. Daculsi, J. Biomed. Mater. Res., 39 (1998), 660.

(9) O. Gauthier, J.M. Bouler, P. Weiss, J. Bosco, E. Aguado and G. Daculsi, Bone, 25(2) (1999) $71 \mathrm{~S}$.

(10) O. Gauthier, D. Boix, G. Grimandi, E. Aguado, J.M. Bouler, P. Weiss and G. Daculsi, J. Periodontol., 70(4) (1999) 375.

(11) H.B. Dick, A.J. Augustin, N. Pfeiffer, J. Cataract Refract. Surg., 26 (2000) 1242.

(12) T.J. Liesegang, Surv. Ophthalmol., 34(1990) 268.

(13) A. Cherng, S. Takagi and L.C. Chow, J. Biomed. Mater. Res., 35 (1997) 273.

(14) G.J. Stewart, Y. Wang and S. Niewiarowski, Biotechniques, 19 (1995) 598.

(15) S. Duggirala and P.P. Deluca, PDA J. Pharm. Sc. Technol., 50(5) (1996) 290.

(16) S. Bohic, P. Weiss, P. Roger and G. Daculsi, J. Mat. Sc. Mat. Med., 11 (2000) 1.

(17) C. Chevillard, Colloïd Pol. Sc., 275 (1997) 537.

(18) C. Despas, A. Walcarius and J. Bessière, Langmuir, 15(9) (1999)3186.

(19) J. Chojnowski, in S.J. Clarson and J.A. Semlyen (Eds.), Siloxane polymers, Ellis Horwood-Ptr Prentice Hall Polymer Science and Technology, Portland, 1993, Chapter 1. 
(20) J. Nawrocki, J. Chromatogr. A, 779 (1997) 29.

(21) X. Bourges, P. Weiss, A. Coudreuse, G. Daculsi and G. Legeay, Biopolymers, (2002) in press.

(22) D. Klemm, B. Philipp, T. Heinze, U. Heinze, W. Wagenknecht, Comprehensive Cellulose Chemistry, Wiley-VCH, Weinheim, 1998; vol. 2.

(23) A.C. Sau, Polymer Preprints, 31(1990) 636.

(24) A.C. Sau and T.G. Majewicz, ACS Symp. Ser., 476 (1992) 265.

(25) M. Lapkowski, P. Weiss, G. Daculsi and A. Dupraz, Composition pour biomatériau. Brevet CNRS. Int Pat. WO 97/05911 (1997).

(26) R. Turczyn, P. Weiss, M. Lapkowsky and G. Daculsi, J. Biomater. Sci. Pol. Ed., 11(2) (2000) 217.

(27) E.R. Pohl and F.D. Osterholtz, Silanes, Surfaces and Interfaces, Leyden, D.E., Gordon and Breach, New York, 1986.

(28) B. Riegel, S. Blittersdorf, W. Kiefer, S. Hofacker, M. Müller and G. Schottner, J. NonCryst. Solids., 226 (1998) 76.

(29) J. Sefcik, S.E. Rankin, S.J. Kirchner and A.V. McCormick, J. Non-Cryst. Solids, 258 (1999) 187.

(30) M. Ernst and E.R. Froesch, Calcif. Tissue Int., 40(1) (1987) 27.

(31) L.D. Shea, D. Wang, R.T. Franceschi and D.J. Mooney, Tissue Eng., 6(6) (2000) 605. 